\section{SCIENTIFIC ENDEAVOUR AND ACHIEVEMENT}

\section{Charles Scott Sherrington}

An Appraisal. By Ragnar Granit. (British Men of Science.) Pp. xii $+188+14$ plates. (London and Edinburgh: Thomas Nelson and Sons, Ltd., 1966.) 42s. net. THIs book is by an eminent Scandinavian physiologist on a great British physiologist. It was written in English and is not a translation; its smooth reading reveals Prof. Granit's command of the language. He is the Director of the Nobel Institute for Neurophysiology in Stockholm, and he twice worked in Sir Charles Sherring ton's laboratory in Oxford in the late twenties. At that period Sherrington, freed from exacting commitments such as being President of the Royal Society, was able to devote much of his time to an active but not too large Honours School and to a group of graduate research workers, many of whose names are to-day familiar in neurophysiology and neurology. His work then was concerned with details of the reflex activity of the spinal cord, including the part played by the muscles and the synaptic connexions of their nerve fibres in this activity.

Sherrington (1857-1952) felt that posterity should judge a man by his work and he expressed dislike of certain long detailed biographies, hoping that nobody would attempt such an exercise on him. This wish has so far been respected. It is true that there are excellent obituaries in the journals, but further biographical writing has been tackled differently. In E. G. T. Liddell's absorbing book The Discovery of Reflexes, the state of nerve physiology and histology is described as it was before and during Sherrington's work for The Integrative Action of the Nervous System. Granit sets out to emphasize how some of the main problems of neurophysiology stem directly from what Sherrington did.

After a brief biographical and historical chapter, Granit goes on to deal with the concepts underlying Sherrington's work, and particularly with inhibition in the nervous system regarded as an active process, which is one of the main landmarks with which Sherrington's name is now associated. His work on this subject is described, as is that of his pupils and contemporaries. Then come chapters on the wider outcome of this pioneer work. First, there are the advances made possible by the development of amplifying devices; particularly by Adrian (Sherrington's joint Nobel Laureate) in recording single nerve impulses. Then comes the investigation of individual parts of the reflex are by the use of microelectrodes. Eccles, by developing this technique, was able to penetrate single motor horn cells in the spinal cord and so get information about the activities of the synapses of an individual cell. This continued Sherrington's "pulling to pieces from the top downwards", but he also prophesied that "the elemental may not prove to be the simple" and one of the problems of to-day is, so to speak, to put the animal together again. Something of this has been taking place in Granit's own laboratory and he writes of the work on reflexes and motor control, and particularly on muscle spindles, which Sherrington had described in 1894 .

The final chapter on Sherrington's writings is largely taken up with a summary of Man on his Nature. This is not an easy book to read, but it is lit up with passages of beauty and insight. There are also quotations from Sherrington's book of poetry The Assaying of Brabantius. For Sherrington, writing was always bound up with the desire to make everything "absolutely clear", and he maintained that this could be done more precisely in Latin or French than in English.

Granit's book is one to read at leisure and from which to allow something of the whole personality of Sherrington to emerge, including his capacity for the accumulation of knowledge, the power to ask the right questions in physiology and the skill to get the answers, all in an individual who was a poet, something of an artist, a lover of nature and a man who could command devotion and respect from those who came in close contact with him and worked under him.

Sybil Cooper Creed

\section{HOW TO SUCCEED IN PAINTING}

\section{The Application of Surface Coatings}

(Paint Technology Manuals, Part 4.) Pp. xiii +345. (London: Chapman and Hall, Ltd., 1965. Published on behalf of the Oil and Colour Chemists' Association.) 35s. net.

\section{The Testing of Paints}

(Plant Technology Manuals, Part 5.) Pp. viii +171. (London: Chapman and Hall, Ltd., 1965. Published on behalf of the Oil and Colour Chemists' Association.) 35s. net.

"'Tis a Dutch proverb, that 'paint costs nothing', such are its preserving qualities in damp climates". This quotation from Emerson serves as a heading to the foreword of Part IV of the Paint Technology Manuals published by the Oil and Colour Chemists' Association. The proverb holds only to the extent that the paint is of good quality, and that the surface has been prepared and the paint properly applied. While it is easier to succeed in painting than in business without really trying, the chances of success are enormously increased by treating the exercise in a careful, planned scientific manner.

Fortunately, this has been realized for many years in large-scale factory application of paint, and the realization is spreading to still wider circles of paint users all the time. The present two volumes, covering the whole of paint technology, should do much to aid the process of education.

Part IV continues the system of earlier volumes whereby each chapter is written by a specialist in that topic. By far the largest portion ( 280 pages) is concerned with various techniques for the industrial application of paint, and the application of decorative and protective coatings for constructional materials gets only 50 pages. After a chapter on equipment for industrial finishing, the material is dealt with in terms of the substrate to be coated, as is almost inevitable in view of the very specific problems found in each industry.

A severely practical outlook permeates the book, and those who expect to find reasons why things happen, or should be done, will seldom find them here; it is essentially a plain man's guide, and at that level will serve a very valuable function. But it is disappointing to find a book devoted to the application of surface coatings that completely ignores any treatment of the rheological properties of paint, and gives no background data on adhesion. Some theoretical background is given in the chapter on industrial metalware, but otherwise such material is conspicuous by its absence.

Part V, The Testing of Paints, differs from the other volumes in that it is essentially the work of one man, F. G. Dunkley, and the treatment is more unified. After a short chapter on test methods for production quality control, there follow chapters on tests for basic properties and tests for specific properties. Basic properties include viscosity, gloss, hardness, flexibility, durability and adhesion, while specific properties cover chemical resistance, fire retardance, electrical properties, basic paint tests and film thickness (surely this is a basic property ?).

The emphasis is on those methods of test in widespread use in Britain, but due reference is made to other tests where these have been found to be useful; an appendix collates the relevant American Society for Testing Materials, British Standard and Ministry of Defence (DEF) specifications. There is a fairly full bibliography, 